\title{
HANFORD WIND SURVEY
}

\section{E.H. Phinney and O.K. Harling}

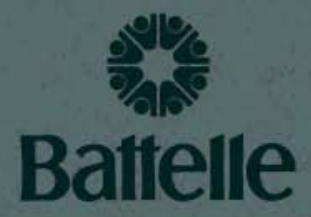

Pacific Northwest Laboratories

Richland, Washington 99352

SEPTEMBER 16, 1974

Prepared for the U.S. Atomic Energy Commission under Contract AT(45-1):1830 
NOTICE

The report was prepared as an account of work sponsored by the United States Government. Neither the United States nor the United States Atomic Energy Commission, nor any of their employees, nor any of their contractors, subcontractors, or their employees, makes any warranty, express or implied, or assumes any legal liability or responsibility for the accuracy, completeness or usefulness of any information, apparatus, product or process disclosed, or represents that its use would not infringe privately owned rights.

PACIFIC NORTHWEST LABORATORY

operated by

BATTELLE

for the

U.S. ATOMIC ENERGY COMMISSION

Under Contract AT(45-1)-1830

\author{
Printed in the United States of America \\ Available from \\ National Technical Information Service \\ U.S. Department of Commerce \\ 5285 Port Royal Road \\ Springfield, Virginia 22151 \\ Price: Printed Copy \$4.00; Microfiche \$1.45
}


BNWL-1859

UC-11, Environmental and Earth Sciences

\section{HANFORD WIND SURVEY}

by

Eric H. Phinney

Atmospheric Sciences Department

and

o. K. Harling

Physics and Instrumentation Department

September 16, 1974

BATTELLE

PACIFIC NORTHWEST LABORATORIES

RICHLAND, WASHINGTON 
HANFORD WIND SURVEY

\section{INTRODUCTION}

This report has the purpose of assessing the suitability of the Hanford Reservation as a potential location for research and development investigations directed towards wind energy conversion methods. It consisted of a modest effort involving a summary and analysis of a limited amount of selected wind speed data from a low elevation site (the Hanford Meteorology Station) and from a high elevation site (the crest of Rattlesnake Mountain). Suggestions are included for potential wind energy $R$ \& $D$ projects which could be efficiently conducted at the Hanford site.

\section{SUMMARY AND CONCLUSIONS}

These preliminary findings indicate that, on an annual basis, the average mean wind speed on the crest of Rattlesnake Mountain is greater than $13 \mathrm{mph}$. It is concluded that the crest of Rattlesnake Mountain on the Hanford Reservation is a suitable site for accomplishing $R$ \& D studies involving wind energy conversion methods.

DISCUSSION

This report presents summaries of frequencies of occurrence of wind speed data acquired at the following locations:

- Hanford Meteorology Tower, elevation $727^{\circ}$ MSL, height of wind sensor $50^{\prime}$

- Rattlesnake Mountain radio-telemetered station, elevation $3568^{\prime} \mathrm{MSL}$, height of wind sensor $9^{\prime}$ (10 miles south of the Hanford Meteorology Tower). 
- Rattlesnake Mountain gust recorder, elevation 3568' MSL, height of wind sensor $10^{\prime}$.

Figures 1 and 2 show the wind sensor installations on the Hanford Meteorology Tower and on the crest of Rattlesnake Mountain. Both locations are equipped with Aerovane wind sensors whose specifications are listed below:

Wind Speed:

$\begin{array}{ll}\text { Range: } & 200 \mathrm{mph} \text { maximum } \\ \text { Accuracy: } & \pm 1.5 \mathrm{mph} \\ \text { Response: } & \text { distance constant* equals } 15 \text { feet of air } \\ \text { Threshold: } & 2.5 \mathrm{mph}\end{array}$

Wind Direction:

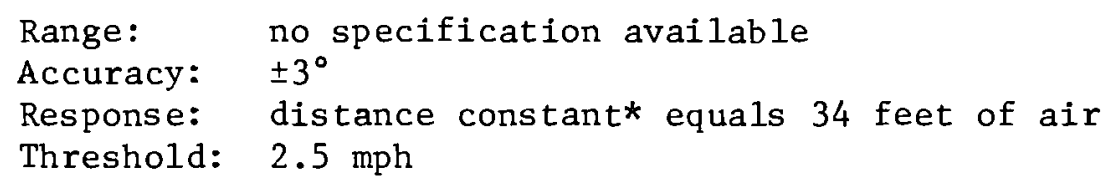

*The distance constant is defined as the feet of air required to pass through the transmitter to give 63 per cent of a sharp change.

The data from the Hanford Meteorology Tower and from one of the sensors on the crest of Rattlesnake Mountain are recorded on strip charts. The data from the other sensor on Rattlesnake Mountain are electronically integrated over an hour, radio-telemetered to a central station, and recorded in digital format.

For this survey, one year (CY 1970) of wind data was summarized for each of the three sensor installations. In addition, a 5-vear period of radio-telemetered data from Rattlesnake Mountain (April 1969 - April 1974) was summarized. Other long period wind summaries for the Hanford Meteorology Tower sensors have been previously compiled. (1) 
Some comments on the type and quality of the data are appropriate, e.g. ,

- Hanford Meteorology Tower data, strip charts, hourly mean wind speeds integrated subjectively, high quality, nearly $100 \%$ data recovery rate, CY 1970 - 8760 data; $1955 / 70$ - 131400 data.

- Rattlesnake Mountain telemetered data, reading taken once every 6 hours, integrated electronically for the last 1-hour period, analogue radio transmission to central station, erratic quality, about $60-65 \%$ data recovery rate (representing about $25 \%$ of the time), $1969 / 74$ - 7424 data, CY 1970 - 1460 data.

- Rattlesnake Mountain strip chart data, hourly mean wind speeds integrated subjectively, good quality, $95 \%$ data recovery rate, CY 1970 - 8760 data.

Figure 3 graphs these sets of data with per cent frequency of occurrence of hourly mean wind speeds by speed class intervals for the entire period of record. Curve plotting points were arbitrarily chosen at the mid-point of each speed class interval. Calm wind speeds were included in the 1-3 mph speed class interval and al1 speeds $\geq 25 \mathrm{mph}$ were considered as one speed class interval.

Curve A represents the long period of record (1955-70) and Curve B represents the short period of record (CY 1970) for the Hanford Meteorology Tower at 50 feet above ground 1eve1. It can be seen that the long term mean wind speed value lies between the 4-7 mph and 8-12 mph speed class intervals (actual value $7.6 \mathrm{mph}$ ). (1) It can also be seen that CY 1970 was somewhat "windier" than the long term. 
TABLE 2

\begin{tabular}{|c|c|c|c|}
\hline $\begin{array}{l}\text { DATE OF } \\
\text { OCCURRENCE }\end{array}$ & $\begin{array}{l}\text { AVERAGE } \\
\text { SPEED (mph) }\end{array}$ & DURATION & $\begin{array}{l}\text { PEAK } \\
\text { GUSTS (mph) }\end{array}$ \\
\hline $2-27-66$ & 83 & - & 103 \\
\hline $1-04-67$ & - & - & 75 \\
\hline $1-29-67$ & - & - & 114 \\
\hline $2-17-67$ & 110 & $1 / 2 \mathrm{hr}$ & 136.5 \\
\hline $10-03-67$ & 97 & $3 \mathrm{hrs}$ & 129 \\
\hline $3-22-69$ & 100 & $1-1 / 4 \mathrm{hrs}$ & - \\
\hline $3-22-69$ & 120 & $1 / 4 \mathrm{hr}$ & 142.5 \\
\hline $12-30-70$ & 100 & - & 118.5 \\
\hline $1-09-71$ & 67 & $\mathrm{hr}$ & 96.5 \\
\hline $1-24-71$ & - & - & 117 \\
\hline $2-10-71$ & - & - & 120 \\
\hline $12-04-71$ & 60 & - & 72 \\
\hline $12-05-71$ & 45 & - & 63 \\
\hline $12-08-71$ & - & - & 87 \\
\hline $1-11-72$ & 120 & $3 / 4 \mathrm{hr}$ & $\begin{array}{r}150+\begin{array}{l}\text { (limit of } \\
\text { recorder) }\end{array}\end{array}$ \\
\hline
\end{tabular}

POSSIBILITIES FOR WIND CONVERSION RESEARCH AND DEVELOPMENT AT THE HANFORD SITE

The world wind energy resource has been estimated to be $1 \%$ of the total solar energy flux or $\sim 50$ Q per year, $\left(Q=10^{18}\right.$ BTU). Projected total world energy consumption for the year 2000 is about 6 Q. The kinetic energy of the wind is, therefore, a relatively large energy resource. In North America about $10 \mathrm{w} / \mathrm{m}^{2}$ is the estimated mean wind energy in the summer, while a kinetic energy of $\sim 15 \mathrm{w} / \mathrm{m}^{2}$ is estimated for the winter. The greater wind energy density in the winter is particularly interesting since the solar energy, which can be collected by most other solar conversion processes, decreases in the winter. Wind energy conversion systems have been able to attain high efficiencies, in excess of $50 \%$, and the technology for utilizing wind energy is relatively advanced. Capital costs are estimated to be in the same range as costs for future nuclear plants. In view of 
these facts, it appears to be in the public interest to pursue an intensive national $R \& D$ effort to develop the conversion and utilization processes for wind energy resources.

This report has presented data concerning the available wind speeds on the Hanford reservation. Year around wind speed averages in the range 7-13 mph are found near ground level on the Hanford reservation and higher mean speeds are probably available at elevations several hundred feet above Rattlesnake Mountain. Wind speeds in this range are attractive from an energy conversion standpoint. The availability of this wind resource, the 1arge pool of technical expertise at Hanford, the availability of a large number of potential test sites on government controlled land, and a heavy commitment to energy related research, combine to make the Hanford site an attractive site for wind energy conversion $R \& D$ programs. Research and development programs, which might advantageously be carried out at the Hanford location include the following:

- Operation of large scale prototypic wind turbines

- Investigations and demonstration of proof of concept for wind energy systems incorporating storage to provide base load capability

- Systems analysis and demonstration of large wind energy storage systems based on hydrogen, pumped water storage in hydroelectric reservoirs and compressed gas storage in the earth

- Systems analysis and demonstration of prototypic or experimental wind energy storage systems for small scale applications, such as residential building power. 


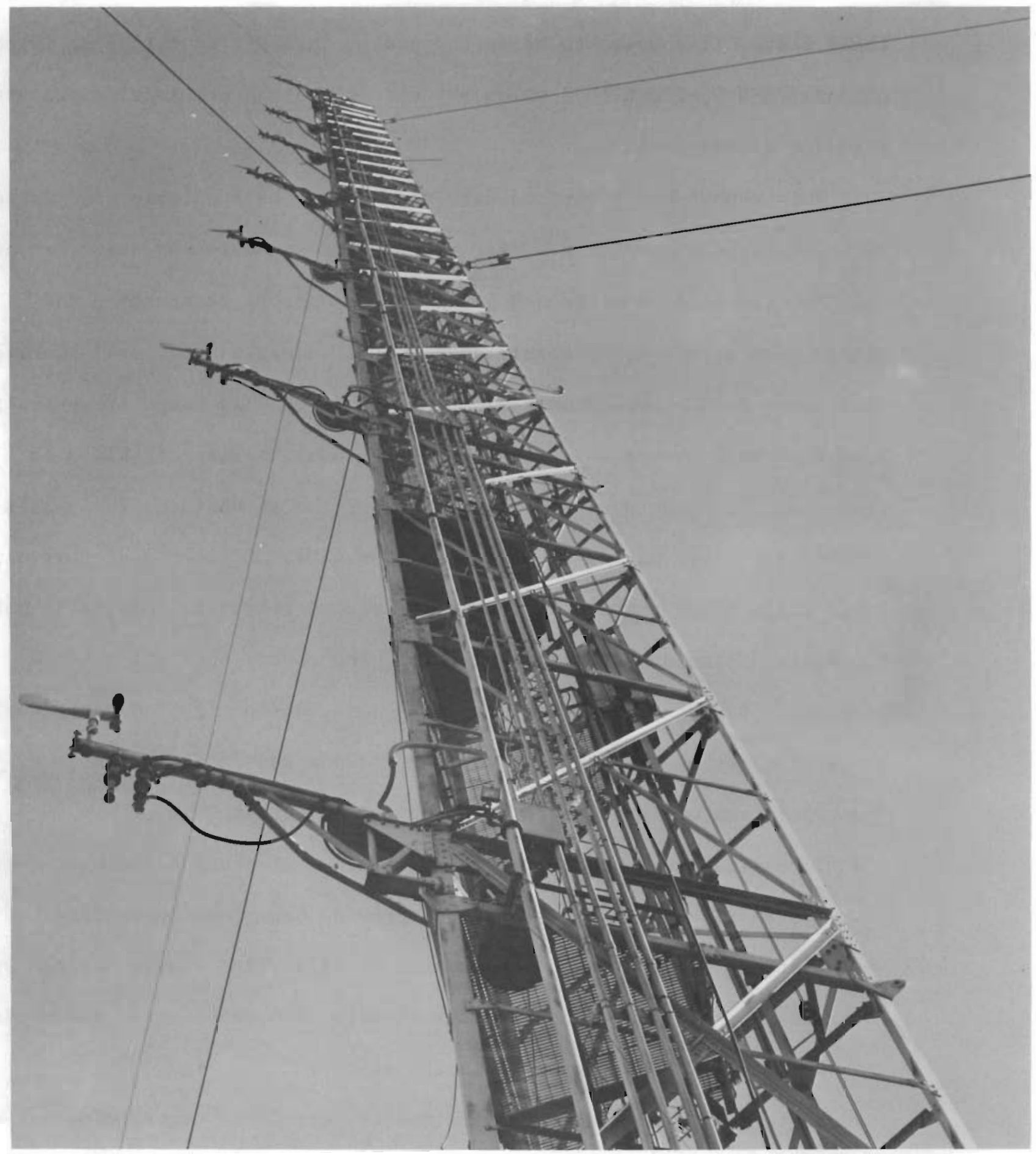

FIGURE 1: The 410-foot Hanford Meteorology Tower operated by BattelleNorthwest (elevation $727^{\prime} \mathrm{msl}$ ) - instrumented booms are mounted every 50 feet except at the 350-foot level. 


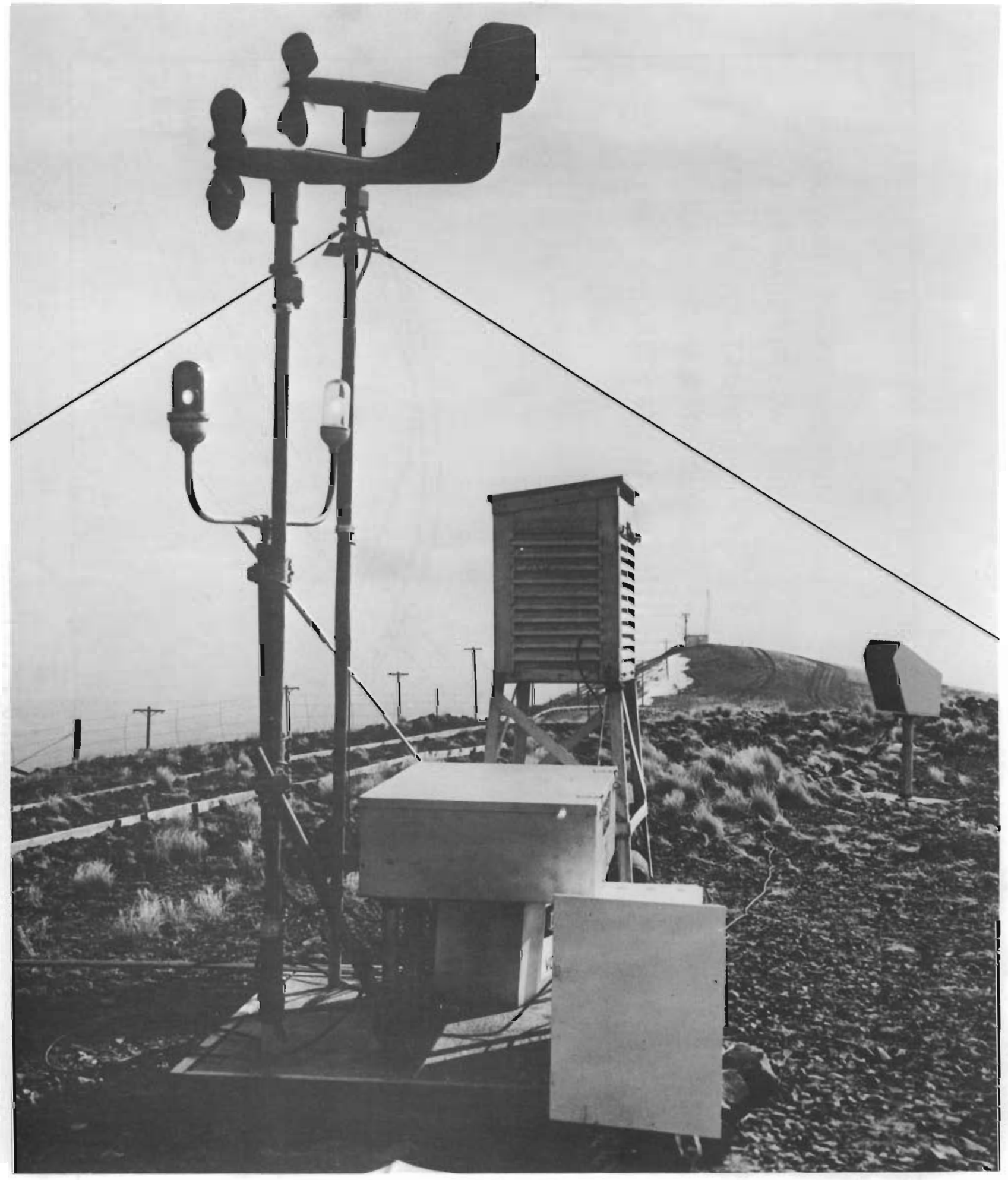

FIGURE 2: Wind sensor insta1lation on crest of Rattlesnake Mountain (elevation $3568^{\circ} \mathrm{ms} 1$ ) 


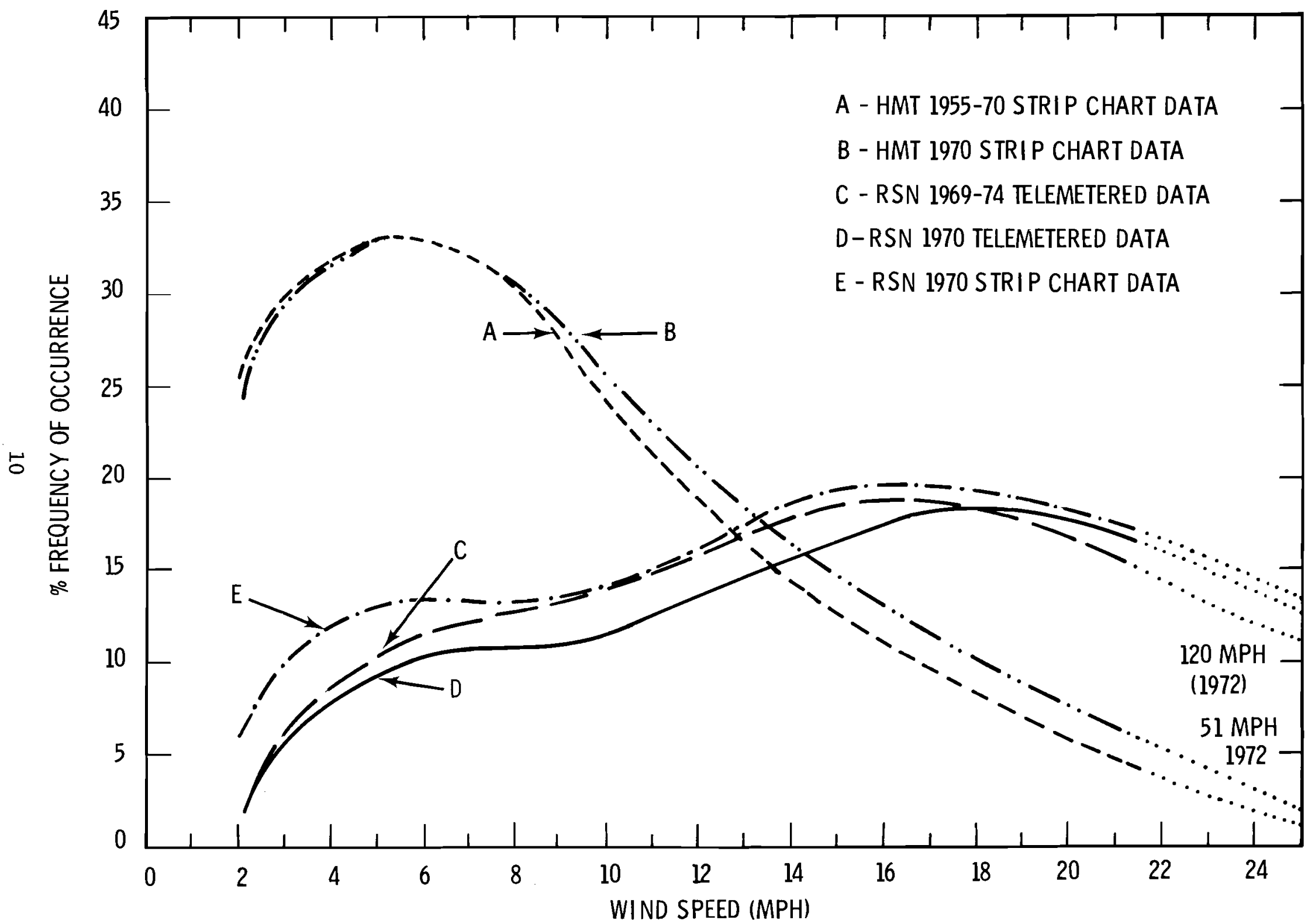

FIGURE 3: Frequency (\%) of occurrence of wind speeds 


\section{ACKNOWLEDGMENTS}

W. A. Stone accomplished the tasks of reading the Rattlesnake Mountain wind speed and direction strip charts as well as the telemetered data logs. W. F. Sandusky accomplished the computer programming for producing these summaries. AEC Special Studies funds supported this work.

\section{REFERENCES}

1. Stone, W. A., et a1., Climatography of the Hanford Area, BNWL-1605, Battelle, Pacific Northwest Laboratories, Richland, Washington, June 1972.

2. Unpublished data. 


\section{DISTRIBUTION}

\author{
No. of \\ Copies \\ OFFSITE \\ 1 AEC Chicago Patent Group \\ U.S. Atomic Energy Commission \\ Argonne, IL 60439
}

A. A. Churm

$196 \frac{\text { AEC Technical Information }}{\text { Center }}$

1 Aerodynamics Organization

Sandia Laboratorles

Albuquerque, New Mexico

87115

1 W. E. Heronemous

University of Massachusetts

Amherst, Massachusetts 01002

1 L. 0. Herwig

NSF-RANN

1800 G. Street

Washington, D.C. 20550

1 G. Hespelp

University of Idaho

Moscow, Idaho 83843

1 E. Wendell Hewson

Dept. of Atmospheric Sciences

Oregon State University

Corvallis, Oregon 97311

3 J. R. Rannels

Division of Applied Technology

U.S. Atomic Energy Commission

Washington, D.C. 20545

1 J. M. Savino

NASA-Lewis Research Center

21000 Brookpark Road

Cleveland, Ohio 44134

1 R. Wilson

Dept. of Mechanical Engtneering

Oregon State Unfversity

Corvallis, Oregon 97331
No. of

Copies

ONSITE

2 AEC Richland Operations office

PFX Dunigan, Jr.

B. J. Melton

69 Battelle-Northwest

E. L. Alpen

D. A. Baker

W. J. Coleman

D. L. Condotta

G. J. Dau

D. E. Deonigi

J. G. DeSteese

R. L. Dillon

K. D. Drumheller

C. E. Elderkin

E. A. Eschbach

J. J. Fuquay

R. L. Gordon

0 . K. Harling (10)

A. J. Haverfield

D. A. Kottwitz

N. Laegreid

D. L. Lessor

T. I. McSweeney

E. H. Phinney

P. M. Potter

J. V. Ramsdell

W. F. Sandusky

L. C. Schmld

C. L. Simpson

W. G. N. Slinn

J. S. Stoakes

W. A. Stone

D. L. Styris

M. T. Thomas

L. L. Wende11

R. K. Woodruff

F. R. Zaloudek 